\author{
Branislav Rabotić \\ College of Tourism, Belgrade, Serbia \\ UDC 338.48-6:7/8(37+38)
}

\title{
SPECIAL-PURPOSE TRAVEL IN ANCIENT TIMES: “TOURISM" BEFORE TOURISM?
}

\begin{abstract}
Tourism is generally regarded as a quite recent phenomenon, but researchers and scholars do not agree on its historical roots: some relate them to the mid-nineteenth century progress of transport infrastructure and the availability of leisure time, others to the Grand Tour as a particular type of aristocratic travel in the 17-18 ${ }^{\text {th }}$ centuries, and some even to mediaeval pilgrimages. However, trips similar to today's tourism were made as early as during the ancient period, when people travelled not only for trade and business, religion, sports, health,
\end{abstract}

"If you have not seen Athens, you're an idiot. If you have seen her and not been captivated, you're a donkey. If you enjoy her charms and then run off, you're a jackass". Lysippus

\section{Introduction}

As an alternative to conventional mass tourism, which has for a while been open to criticism, the so-called special interest tourism is being more frequently mentioned. ${ }^{1}$

1 In academic literature, the term "niche tourism" is also used (Robinson \& Novelli, 2005), as well as "thematic tourism" (Wong \& Cheung, 1999). Among tourism professionals in former Yugoslavia a phrase "selective forms of tourism" was coined in the 1970s, and it is education and other specific reasons, but also for leisure and pleasure involving sightseeing of the new and unfamiliar areas. The aim of this paper is to bring together the insights of the literature on travel in the ancient Graeco-Roman world and, particularly, on special-purpose trips which might be seen as a distant forerunner of some modern forms of tourism.

Key words: special interest tourism, tourism history, ancient travel, Graeco-Roman world

In this respect, some authors divide tourists into "old" and "new" (Krippendorf, 1986; Poon 1993), depending on the motivation and the mode of transport, the activity they pursue in the destination and the impact they make on the environment and society. The "new tourists" seek personally adjusted travel experiences, a sense of inner fulfilment and satisfaction. In fact, many features of trips in the past are back in the ascendant - initiative, curiosity, challenge of the new, getting off the beaten track, exploration, discovery, risk, excitement, physical effort, slow mobility, mingling with the locals, etc. So it appears that special interest tourism of today brings sense, purpose and individuality back to the tourist travel.

Trips motivated by special needs and interests are not a new phenomenon. On

still used in Serbian and Croatian reference books (Rabotić, 2013). 
the contrary, yet back in the ancient times, people travelled for business, sports, religion, health, festivals, including visits to renowned cities. Are those trips, verified by both written and some archaeological sources from antiquity, the genuine forerunner of today's tourism, and, in particular, special interest tourism? Can one even claim that they represent the earliest rudimentary form of "tourism"? Or perhaps the term "ancient tourism" is rather misleading because it invites direct analogies with the seasonal mass movements of today. This is something that tourism researchers, on the one side, and historians or classical philologists, on the other side, do not concur on.

\section{The ancient roots of tourism?}

From Vukonićs point of view (2012) one cannot argue about the existence of tourism in earlier historical periods. He relates this reason to the concept of free time as one of the basic requirements for the development of tourism and points out that "the middle of the nineteenth century is the most appropriate time to consider the emergence of tourism as a modern-day phenomenon" (p. 7). On the other side, Chambers (2010, p. 11) notes:

Much of the earlier scholarship devoted to the history of tourism justifies its focus on the Western experience with the argument that modern tourism was made possible by the increased opportunities for leisure and recreation that accompanied the growth of Western capitalism... [T] here is scant evidence to support the idea that opportunities for leisure have invariably increased with recent changes in social organization and economic development. To the contrary, many preindustrial peoples may actually have greater amounts of leisure time.
The fact is that the limited links between tourism research and history have led people to believe that tourism is a new phenomenon (Andriotis, 2009). Walton (2009a, p. 24) states that the relevance of tourism history "will often go back long before the immediate past, as phenomena regarded as new or recent have much deeper, and more revealing, roots than appear at first sight".

Although modern-day tourism could not have existed in the previous centuries, on no account can one claim that "tourists" did not exist back in the ancient past. Thus, Gyr (2012) argues that recreational and educational travel already existed in the classical world and, even earlier, in Egypt under the pharaohs. In the latter, there is evidence of journeys emanating from a luxury lifestyle and the search for experience, amusement and relaxation. Also, according to Casson (1994) evident signs of tourism, that is, trips for leisure and curiosity reasons can be traced back to the New Empire times, circa 1500 BCE.

Historical origin of tourism Page \& Connell (2009) notice in the ancient cultures of the Greek and Roman social elite stating that "these early 'tourists' pursued pleasure and relaxation in regions away from the main towns and cities, they epitomize modernday tourism: the pursuit of pleasure in a location away from everyday life and the use of one's leisure time for non-work purposes" (p. 25). Ancient Greeks and Romans devoted considerable attention to leisure, pleasure, and travel; even they had a concept associated with vacations, the feriae (Korstanje \& Busby, 2010). Lascaratos (1978) holds it true that in ancient times there were genuine tourists widely known for their travel accounts such as Herodotus, Pausanias and Strabo: "The list also includes all ancient Greek authors and philosophers known for travelling abroad in order to familiarise themselves with the wisdom and culture of other peoples" (p. 26). ${ }^{2}$ Herodotus, "the fa-

\footnotetext{
2 The term tourist was not indeed used in
} the ancient times, but Greek words $\theta \varepsilon \omega \rho i \alpha$ 
ther of history" and a genuine travel writer, practically spent the whole life as a tourist creatively utilising his experiences. He was a seasoned traveller and a paragon of sophisticated intellectuality (Casson, 1994).

Having in mind such views, Enzensberger (1983, p. 122) with all reason makes a point: " $[\mathrm{H}]$ ow do we justify historically isolating something called tourism from something that has always existed, as if it were something unique? ${ }^{3}$ Walton (2009b, p. 783) also states: "There remain plenty of issues to resolve as regards the origins of 'modern' tourism, not least in relation to older phenomena such as pilgrimage and the extent and significance of recognisable forms of tourist activity in the ancient Mediterranean".

To argue for a return to the ancient civilizations and their conceptions and practices of "tourist travel" may nowadays appear unusual and strange, because we are virtually "at a significant juncture between the early successes of the orbital space tourism industry, and the very near promise of the start of sub-orbital space tourism operations" (Webber, 2013, p. 138)

According to Verhoeven (2013), drawing parallels between present-day tourism and its pre-modern prototypes, such as the Grand Tour, mediaeval pilgrimages or Roman trips, is considered simplistic and highly anachronistic by many researchers and social scientists working under the umbrella of tourism studies. Moreover, Vukonić (2010) criticises the authors who, according to his words, frequently exceed in looking for the cause of phenomena in the ancient past or the ones who had tried to ascribe the fea-

and $\theta \varepsilon \omega \rho o ́ \varsigma$ evoked the activity of sightseeing. Herodotus himself uses the term $\kappa \alpha \tau \dot{\alpha}$ $\theta \varepsilon \omega \rho i \sigma \eta \varsigma$ to describe Solon's sightseeing journey during his self-imposed ten-year exile from Athens (Stark, 2009).

3 From the English version of Enzensberger's text: http://mestrantroponova.files.wordpress. com/2008/11/hans-magnus-enzensberger.pdf [Accessed 9 October 2013]. tures of present phenomena to the past ones. He simply views it as "forcing of history" (p. 9) wondering if there is much sense in it.

Nevertheless, "[r]elations with the past can neither be proscribed nor prescribed, for they are bound up with all our ideas and institutions" (Lowenthal, 1999, p. xxv). A historical insight helps us to better grasp the processes and behaviour relating to a certain aspect of life in the past, resulting in why the modern world is the way it is. Danish existentialist philosopher and social critic Søren Kierkegaard (1813-1855) rightly claimed that life can only be understood backwards. ${ }^{4}$ The same thing is applicable to tourism: "Despite the variety of approaches, a central concern of history is understanding change through time. It is this distinctive view which forms history's contribution to tourism studies" (Towner \& Wall, 1992, p. 73).

\section{Travel and "tourism" in the graeco-roman era}

Travel is one of the most ancient and common aspects of human life and it can be traced back to mythical times. Ancient peoples - the Egyptians, Babylonians, Phoenicians, Cretans, Jews and Greeks - who were initially focused on themselves and regarded their respective countries the centre of the world (to ancient Greeks Apollo's Delphi was "navel of the world") began, some time later, to meet neighbours and other peoples by travelling to their countries, exchanging goods, sharing experience and building up their spiritual life.

The first great travellers were the Greeks, a people who were willing to share the findings of their discoveries and observations with the rest of the world, unlike the Phoenicians who jealously kept their findings, even spreading false information in order to keep

\footnotetext{
http://history.csusb.edu/facultyStaff/History306/documents/HistoryQuotations8_16_ 96.pdf [Accessed 20 October 2013].
} 
the trade monopoly (Maksimović, 1951). The Greeks travelled not only for trading purposes, religious needs, visits to the events such as Olympic Games, cure-finding reasons, but for pleasure as well: "A number of Greeks went to Egypt, some, as was natural, for trade, some on the expedition, and some to see that country" (Herodotus, cited in Dillon \& Garland, 2010, p. 275). The fascination that Egypt held for the classical world is well known. This is born out by celebrated visits such as those made by Solon or Pythagoras.

It is widely known that the ancient Greece was the cradle of hospitality, since perfect strangers were treated with respect and attention. Xenius Zeus, the father of gods and god of hospitality protected foreign visitors. As a matter of fact, hospitality was a way to worship the gods, or was done out of fear of the gods, yet it maintained a socially important rule of the culture, a rule without which the culture would suffer greatly. ${ }^{5}$ Some city-states, like Corinth or Athens, willingly welcomed foreigners taking into account the economic benefit and a way to build up their "reputation". In that respect, militant and xenophobic Sparta was an exception: "[F]oreign visitors were admitted only grudgingly, and from time to time summarily expelled: foreign ideas must at all costs be kept out" (Kitto, 1950, p. 91).

Owing to her favourable geographic position in the north of the Peloponnese, Corinth was a thriving trading hub with two docks, one to the Ionian Sea, other to the Aegean Sea, as well as with a special infrastructure for hauling ships across the land (Diolkos, circa 600 BCE). Such an exceptionally lively, vibrant, intriguing and pricey city was "The Paris or Amsterdam of the ancient world". The city was specially renowned for her hetaerae (courtesans), the temple prostitutes who served the wealthy merchants traveling in and out of the city: "And therefore it was also on account of these women that the city

5 http://www.crowdog.net/hospitality.html [Accessed 4 November 2013]. was crowded with people and grew rich; for instance, the ship captains freely squandered their money, and hence the proverb 'Not for every man is the voyage to Corinth"' (Strab. 8.6.20 $)^{6}$. When in Corinth a traveller could succumb to the carnal pleasures, whereas a visit to the polis of Athenians was a cultural challenge primarily.

When, in the 5th century BCE, the Periclean Athens gained the reputation of "the school of Hellas" for intellectual, artistic, and material pre-eminence (whose most prominent feature was the newly-built Parthenon on the Acropolis), it became appealing to the visitors. The very settlement, with winding alleys of well-trodden ground (unlike Alexandria boulevards) and humble homes (houses) was uneventful, so it is possible to conceive the admirations of the visitors who set foot to the plateau of the sacred Athenian hill. Except for the cultural experience, Athens was offering a lively, enjoyable time to those who visited it to take part in the great fiesta called City Dionysia "when visitors from any city in Greece might be expected" (Kitto, 1950, p. 36).

The Romans were the heirs of the Greek (Hellenistic) world, its traditions, its world of ideas and its territories. Of all countries in Rome's control Egypt had the oldest historical tradition. Its history, for which monuments of incredible size and age were visual proof, reached back into remote times and yet existed beyond a merely mythological context (Takács, 1995). This country as a whole was "a tourist paradise offering Romans an exotic landscape, a different way of life, unusual monuments and relatively easy travel" (Lomine, 2005, p. 74). The crowds went every year from Italy and Greece to Egypt, which had a constant service with Italy in the shipping season: "[t]he average voyage from Puteoli [the harbour of Rome] to Alexandria with a good wind was at least

6 http://www.perseus.tufts.edu/hopper/text? doc $=$ Strab.\%208.6.20\&lang=original [Accessed 10 October 2013]. 
twelve days; nine, according to Pliny the Elder, the fastest" (Friedländer, 1965, p. 352). In the coastal area of the largest Mediterranean port then, one could also see the Arabs, Persians, Ethiopians, Indians and many others. There were various foreign quarters and

....an entertainment district lined with nightclubs. Unus illis deus Nummus est, 'They worship only one god there-Cash', someone once grumbled. It was not completely true. If Alexandria was the Marseilles of the ancient world, it was also the Vienna, a city of passionate lovers of music... Alexandria was a Greek city with a cosmopolitan overlay. For the real Egypt, the tourist had to go up the Nile" (Casson, 1994, pp. 258-259, italics in original).

Classical Rome gave impetus to travelling and particular forms of holiday. Holiday travel became increasingly frequent due to the development of infrastructure. Around $300 \mathrm{CE}$, there existed a road network with 90,000 kilometers of major thoroughfares and 200,000 kilometres of smaller rural roads (Gyr, 2012). Combined with the transport system, three other factors were important contributors to "tourism" during the Roman Era: a common coinage, language, and legal system (Hudman \& Jackson, 2003): “Travelling throughout most of the Roman Empire was easy, swift and secure to a degree unknown until the beginning of the nineteenth century; occasions for changing residence were far more numerous than to-day, and water and land alike alive with trade and travel" (Friedländer, 1965, p. 268). ${ }^{7}$

Then there were "seaside resorts... where the upper classes and the masses flocked each summer to get away from the over-

When interpreting some Friedländer's comments one should take into account that his book, which represents one of the first major studies of relevance to tourism history, was published in 1907. crowded and unhealthy conditions in Rome" (Page \& Connell, 2009, p. 25). Tourists in Bay of Naples, which was a hundred miles away from Rome, "could rent rooms in the many boardinghouses that were clustered near the shore; they could lounge in beachside restaurants and popinae (bars)" (Perrottet, 2003, p. 67). The well-off Romans passed time on the beaches of Egypt and Greece as well. Therefore, Feifer (1985, p. 8) states that "the first culture genuinely to produce mass tourism, in both the letter and the spirit of the term, was Imperial Rome".

"Roman tourism" reached its peak in the 2nd century CE owing to pax Romana, which procured more stable political conditions for travelling. At that time, a large number of Roman visitors travelled to Greece because of its fabled mythology, its monuments and its Olympic Games and other festivals. Hadrian, "the most widely travelled of the Roman emperors" (Casson, 1994, p. 286) restored and enlarged "Theseus's Athens", adorning it with new and stunning buildings, still verifiable by the inscription in the triumphal arch built in his honour. The Romans, like today's tourists who visit numerous European churches and cathedrals, visited a temple by temple: "the sacred plateau [of the Acropolis] was filled with people - not just Roman tourists, worshipers, and their guides, but officials and religious functionaries, astrologers, priestesses, maintenance workers, porters, and even police to protect the valuable temple artefacts" (Perrottet, 2003, p. 123).

For certain notable Roman travellers, such as general Lucius Aemilius Paulus, who toured Greece in $167 \mathrm{BCE}$, we are familiar with their itinerary and sightseeing schedule (Mee \& Spawforth, 2001). Most places that the general visited are even today included in the itineraries of four-day tours organised by Athens based sightseeing operators (Athens, the Isthmus, Corinth and Acrocorinth, Argos, Epidaurus, Sparta, Olympia, Delphi, etc).

Ancient travellers had many of the characteristics of their later counterparts. In the 
same manner, tourists carved their "graffiti" signs in the stones of the Egyptian pyramids and other monuments as a testimony of their visit, whereas local stonecutters made such inscriptions for high-class visitors, exemplified by the Colossi of Memnon (Pharaoh Amenhotep III) in the Theban necropolis. "Tourist behaviour" included purchasing souvenirs as travel mementos, shopping items for friends and relatives, and, as it is the case of a mass gathering of today's tourists, dropping the litter behind (Casson, 1994).

The equivalent of Herodotus who lived six centuries earlier, in the 2 nd century CE was Pausanias, a travel writer, who, in all accounts, travelled across Italy, the largest part of Asia Minor, Syria, Palestine and Egypt, while describing the Greek lands in ten volumes. Today, we have only a small fragment of his Description of Greece, which at that ancient time could have been used as tourist reading. His lines clearly state that he was primarily attracted to sanctuary sites, but he also notes many other sights that are not of religious nature: "Pausanias' work therefore informs us not only that tourism did exist in Roman Greece but also that sanctuary sites were predominant destinations for tourists" (Stark, 2009, pp. 39-40). His intentions were to describe the sights particularly emphasizing those most worth seeing and "which even in his day could be said to be 'of special interest only"' (Mee \& Spawforth, 2001, p. 43). It is difficult to say what travellers Pausanias had in mind, but it is evident that the account hinted at his contemporaries.

There were also guides referred to on several occasions by Herodotus in his History. They lived and worked not only in Egypt, but in Greece as well, where they were seen by Pausanias. He refers to them as to $\dot{\varepsilon} \xi \eta \gamma \eta \tau$ i (expounders), with one guide's name noted down ("Aristarchus, the guide to the sights at Olympia"). ${ }^{8}$ They led people around, point-

8 http://www.theoi.com/Text/Pausanias5B. html [Accessed 14 November 2013]. ed out notable sights - temples, altars and statues, described the local rituals, explained customs, and told traditional stories of historical and mythical events associated with the place. Therefore, Lomine (2005, p. 83) claims: "Guides also had an important function as culture brokers".

So, there are views that over the last centuries of the Roman Empire "tourism before tourism" really existed. Even though it was the minority, not the majority of travellers, one cannot contest the amusing and recreational, or cultural aspect of those ancient trips. The "ancient tourism", motivated by interests in classical art and architecture in particular regions of the Empire, Pretzler (2007) links closely with Grand Tour travels which took place many centuries later.

\section{Trade related trips}

The first people who left of their own will were merchants. Trips made for commercial, that is, trading reasons have been long-established, with some ancient nations being very famous for such trips.

In Greek times trade trips were made chiefly by sea. One can claim that the sea broadened horizons and ensured that the Greeks did not remain isolated from one another: "[U]ltimately, their ships reached the central and eastern Mediterranean and established the overseas contacts which would prove so fruitful" (Mee \& Spawforth, 2001, p. 3). These trips became by far safer since the era of Pericles due to the control which the Greek navy gained after the battle of Salamis (480 BCE) and the establishment of Delian League under Athenian leadership. Ships could sail without any fear of the pirates with the perils only lurking from the restless sea. Ships set sail and navigated by day, within an easy reach of the mainland, since navigating at night was precarious due to the lack of high-quality maps, compasses and lighthouses (Flacelière, 1979). There 
were no passenger ships, so the ones who wished to travel across the sea reached the shore and found their way to the merchant ship heading towards their final or some transient destination (Garland, 2007).

Travelling by land was more challenging, since, all the way until the Roman times, roads were of poor quality, more or less trodden paths. Traders carried their goods in pack-saddles of a donkey or a mule which could be harnessed into "a two-wheeled cart or a four-wheeled wagon, both of which had been invented by the third millennium B.C.E." (Garland, 2007, p. 247). Wealthy travellers made trips on a horse. Others usually travelled on foot, even covering long distances, often as long as 30 kilometres per day. In order to get from Athens to Olympia, which in Crowthon's words (2007, p. 48) was "an enormous, time-consuming and dangerous undertaking", it took them five or six days of walking in one direction.

Along with the mountainous terrain and very rare bridges over the rivers, robbers posed a threat to travellers, so trip-makers wore only the basic necessities, journeyed in groups or accompanied by their slaves. Even the mythical Theseus was warned, when he travelled to Athens to claim his throne, that "the road was infested with robbers". During Roman times, especially as of the 2nd century $\mathrm{CE}$ and later on, bandits assaulted, abducted, and even killed travellers in the course of their raids, and the evidence suggests that the ordinary person sometimes journeyed at a great risk. Apart from the recorded cases, headstones also witness the death caused by bandits all over the empire, with the cause of death inscribed: "interfectus a latronibus (killed by bandits)" (Blumell, 2007, p. 11).

Travellers seldom had the opportunity to stay over at inns, with a burden of food self-provision. Such accommodation was

9 http://citeseerx.ist.psu.edu/viewdoc/downlo ad?doi=10.1.1.196.2591\&rep=rep1\&type $=$ pd f [Accessed 19 October, 2013]. not comfortable or appropriate, judging by Aristophanes' comments that Piraeus inns had a reputation for discomfort, prostitution, and bedbugs (Garland, 2007). In the Roman times, the number of lodging facilities was by far larger, in cities in particular "[b]ut, most inns were probably third-rate" (Friedländer, 1965, p. 289). It does not seem to be strange at all that it was widely held among the ancient nations, the Romans as well, that making a trip was "a necessary evil", having in mind how people travelled, where they spent the night, the food they consumed, and the means of transport at their disposal (Vasoli, 1967).

\section{Religious, event and sports related trips}

In the ancient world many thousands of people travelled to sites of religious importance such as the temple of Isis on Philae Island in Egypt and the sanctuary of Apollo at Delphi in Greece: "Although the majority of these people travelled to these sites to worship and therefore have often been labelled as 'pilgrims', some, especially in Roman times, seem to have engaged in activities that are more commonly associated with the modern day 'tourist"' (Stark, 2009, p. 10). The majority of pilgrimage trips in Greece in the archaic period were made by individuals who, for various reasons, visited a particular holy site, and the organization of "official pilgrimages" may have developed more gradually (Jonkers, 2012). The ancient Greeks devoted much of their lives to religious expressions. There were numerous events organised to celebrate gods, Herodotus claims, both in Egypt and Greece.

Panhellenic festivals were very much a part of the Greek way of life and the right of worshippers to travel to and from these festivals was carefully protected. For reasons which are nowadays difficult to explain, four festivals singled out for their significance: the Olympic Games in Olympia, the Py- 
thian Games at Delphi, the Isthmian Games on Isthmus of Corinth and the Nemean Games, gathering athletes, artists, officials, and spectators from all over the Greek world "and even tyrants from Sicily and Greek kings from Cyrene regularly sent chariots to compete at the Olympic and Pythian Games, while poets such as Pindar and Bacchylides celebrated their victories" (Dillon \& Garland, 2010, p. 74). Despite the devotion to the deity, such events offered a visitor

...the feeling of being part of a great event and of enjoying a special experience; a gay festive mood punctuated by exalted religious moments; elaborate pageantry; the excitement of contests between performers of the highest calibre - and, on top of all this, a chance to wander among famous buildings and works of art (Casson, 1994, p. 77).

Since Greek city-states had their own local sanctuaries, Scullion (2007) raises doubts of the purely religious motive for the visit:

Why did some Greek states and well-to-do individuals travel to $[\mathrm{P}]$ anhellenic sanctuaries? Why not rest content with one's local cults? Was there any compelling religious motivation for travelling to Olympia or Epidaurus or Delphi, or were the primary attractions the wider fame, greater prestige, bigger crowds, and better shows? (p. 128, italics in original)

Delphi was visited not only by the Greeks but also by numerous foreigners. Among the visitors there were kings and military leaders (such as wealthy Croesus, Alexander the Great and several Roman emperors), city representatives and masses of common people. Everybody tended to visit this spiritual centre of Greece to get Apollo's advice, whose wisdom was conveyed to people through the Delphian oracle, in order to participate in the Pythian Games in honour of Apollo (named after the serpent, Python, which Apollo slew there) or view a unique "exhibition" of architectural and artistic achievements. The visitors must have stood speechless in front of the immense wealth and spoils of war displayed in the so-called treasuries, purpose-built by individual citystates. As a matter of fact, nowhere in Greece could one see so much gold and "materialised" glory in one place ("A veritable Fort Knox", Casson 1994, p. 240) in the environment of spectacular mountain scenery. Scullion (2007, p. 129) holds that "Delphi's preeminence was surely based not on specifically religious grounds but on its antiquity and high repute, its powerfully impressive setting and rich mythology, and above all on the political capital it had amassed".

In Roman times, Delphi attracted "tourists" with its magnetic charms, and the fact is that wherever tourists flock to tourism business starts thriving. Beside the sellers of overpriced souvenirs, visitors could not put up with pushy guides as well, who, as one of Plutarch's characters in a sketch grumbles about, prevented people from a relaxed sightseeing: "[T]he guides went through their standard speech, paying no attention whatsoever to our entreaties to cut the talk short and leave out most of the explanations on the inscriptions and epitaphs" (Lomine, 2005, p. 83).

Unlike "the cosmopolitan air" of Delphi, Olympia was meant for "national gathering". The Olympic Games, in which only free Greeks took part, raised awareness of the fact that, although they were divided by state borders, political systems, mountains, seas, and quite often by mutual wars, they all belonged to the same Hellenic world.

In the vicinity of today's Olympia, in the late 19th century, the remnants of the Zeus sanctuary were discovered. This site is the cradle of the Olympic Games, which initially were a local event, and in due time, owing to the sacred truce, became Panhellenic. The Games enticed contestants from vari- 
ous Greek poleis, including remote colonies. Within the Altis ("grove") was the grand Temple of Zeus (whose meagre remnants can be seen even today) which housed one of the Seven Wonders of the World: the seated statue of Zeus, a masterpiece produced by famous Phidias. There was an adequate sports infrastructure with numerous facilities such as the stadium with earthen banks (without seats), which could hold forty thousand spectators. A "luxury hotel" (katagogeion), intended for the official guests, was named after the donor from the Naxos island who erected it in the 4th century BCE - Leonidaion (Phoca and Valavanis, 1999).

Around the time of the Games, it was lively with an almost "carnivalesque" atmosphere enhanced by numerous food and beverage sellers, guides and travelling salesmen with plenty souvenirs, etc. There were all kinds of visitors: some coming to watch sports events, others to listen to the speeches of great writers and philosophers (since the games were a festival that transcended sport), or for religious reasons (Crowther, 2007). They all had an interesting, but not a pleasant stay whatsoever, because of unbearable hustle and bustle, summer heats with sudden showers, poor hygiene, sleeping in the tents or in the open sky. Thus, the story that Casson (1994, p. 79) retells that one ancient master "brought an unruly slave into line simply by threatening to take him along to the Olympics" stands to reason. Imagining an indescribable noise in the stadium, Perrottet (2002, p. 161) makes the following comment: "Surviving as a spectator in the Stadium deserved a laurel wreath [the official prize of the Games] in itself". In spite of that, as Crowther (2007) states, there were individuals who came back several times, and one baker from Northern Greece "journeyed to Olympia on no fewer than 12 occasions over 40 years, or for most of his adult life" (p. 49).

Greek sanctuaries with temples, altars and statues were, at the times of Romans, a type of art museums. Visitors went there drawn by "the opportunity to see great works of art or historical buildings and monuments" (Casson, 1994, p. 271) or, in Pretzler's words (2007, p. 42), "for the experience of encountering landscapes or monuments that had a special cultural significance for them". Olympia, like other sanctuaries, became part of the tourist route, and many viewed the visit as an educational experience: "History... was the main incentive for Roman tourists" (Friedländer, 1965, p. 378). There were also the ones who wished to sightsee, but on many occasions they also wished to sacrifice and make other dedications. Stark (2009) argues that such travellers cannot be classified solely as tourists, but are best classed as religious tourists since their journeys included elements of both tourism and pilgrimage.

\section{Health related trips}

It is needless to say that as early as ancient times people travelled to far-away regions in order to find cure. Medicine, already developed in Egypt, had been long-established in Greece as well, as of Homeric times (Flacelière, 1979). Ancient Greece is considered the home of rational medicine with two most important medical schools of Kos (an island famous for the legendary "father of medicine", Hippocrates) and Knidos. Nevertheless, secular and religious (or the temple) medicine were not mutually exclusive. The Greek god of medicine and healing, Asclepios, whose mythological origin emphasizes his position relative to the gods and mankind (as a demigod - a son of Apollo and a beautiful mortal of royal origin), became a symbol of "a blend of sacred and secular medicine” (Geldard, 1989, p. 255).

Because of the desired reputation, several Greek towns had claimed to be the hometown of Asclepios, with Epidaurus on the Peloponnese being the most successful. Its Panhellenic fame was enhanced by 
plague striking Athens in the late 5th century $\mathrm{BCE}$, and the next century brought about the programme of a sumptuous restoration of the sanctuary. Then Epidaurus, like Olympia, got its impressive katagogeion "with 160 rooms on two floors laid out round four peristyle courtyards" (Phoca and Valavanis, 1999, p. 54).

Thousands of sick people flocked to Epidaurus convinced that while sleeping in the hall called abaton, they would be healed by Asclepios either by being hand-touched the aching part or be prescribed the medicine to be consumed as of the following day. Many of the sick, as Delcourt states (1992), were really cured, even under material conditions when the only outcome one could expect is the illness deterioration:

Such cure of illnesses we cannot explain either rationally (because we cannot talk about the existence of any special medicine in Epidaurus, and the priests did not practise any of it), or irrationally, since the described miracles could not be usually ascribed to suggestion (p. 9; translated from the Serbian edition of the book).

The author argues that inscriptions in the stelae about miraculous curing (today at the local museum) are an act of a buffoonery and a con. They claim that a semi-blind woman was given its eyesight back, a dumb child was given back the power to speak, and a man suddenly cured from an ulcer (Flacelièrer, 1979). Even some contemporaries, such as Aristophanes, ridiculed the archive of the curing, which did not prevent Epidaurus from becoming the most popular Greek sanctuary.

During the Hellenistic period the sanctuary was still famous. After it was looted by the Roman Sulla and a little later the pirates in $86 \mathrm{BCE}$, it lived a new period of flourishing after the 2nd century CE. The healing sanctuary attracted a large number of people "like a swarm of bees of flies gathered round a dish of milk and the visitors were true 'walkers of god"' (Simón, 2010, p. 228). Wealthy patients came from all parts of the Empire and their votive offerings were placed on the walls of the sanctuary as evidence of the healing powers of Asclepios. ${ }^{10}$ At that time, as it appears, it was a place where minor surgical operations were performed verified by the uncovered "medical instruments", now on display at Epidaurus museum.

The Greeks familiarised the Romans not only with the cult of Asclepios, but also with medicinal springs. A visit to a spa was, at Roman times, a social event, a kind of socialising and mingling opportunity. For such reasons, many people, not only the sick ones, made such visits. Travellers also used the benefits of the mineral water, illustrated by the case of certain Spaniards from Cadiz who immortalised their visit to Terme di Vicarello (Aquae Apollinares) on four silver objects and as an expression of gratitude offered it to the deity of the spring (Casson, 1994). Unlike the mentioned spa centre, others that were famous in Roman times exist even today - Aquae Calidae (Vichy), Aquae Sextiae (Aix-en-Provence), Aquae Sulis (Bath), Aquae Mattiacae (Wiesbaden), etc.

\section{Conclusion}

Although from the perspective of today's tourism it seems that the ancient period does not appear to be "the most appropriate time to consider the emergence of tourism" (Vukonić, 2012, p. 7), it gave birth to the trips which are by their features and participants' motivation and behaviour quite similar to today's travel. Lomine (2005) notices similarities between Roman tourists

10 This is why the Christian teachers in the early centuries of our era "found it more difficult to displace Asclepios than any other of the gods of Greece or Rome from the beliefs of their converts" (Caton, 1914, p. 70). 
and their present day counterparts "from their gaze and motivations to their concern for safety and entertainment" (p. 85), while García Romero (2013) underlines the fact that ancient travellers had three main motives - religion, sport and culture, for which they travelled, as he puts it, to the destinations of "religious tourism", "sports tourism" and "cultural tourism" (p. 146).

Because of the context in which they happened, immanent features of the ancient trips were physical challenge, otherness, exotic, authenticity, liminality, slow mobility, experiencing local culture and lifestyles, mingling with locals, etc., which are the concepts today ascribed to the trips of "noninstitutionalized tourists" (Cohen, 1972), "new tourists" (Krippendorf, 1986; Poon, 1993), or special interest tourists who are in search of a meaningful, active, exciting and individually tailored experience. Their ancient predecessors probably did not always perceive all these as a pleasure if one bears in mind the hardships and huge physical effort of the then trip-making.

Special-purpose travel in the GraecoRoman world can be seen as a distant precursor of certain forms of today's tourism, particularly business, religious, event, sports and health tourism, though there was also "urban tourism" and even "dark tourism" (Lennon \& Foley, 2000) in the form of visits to the sites of great battles (Marathon or Chaeronea) or misfortunate mythical events, or to the graves of numerous Greek heroes. Although it is held that adventure tourism is of more recent origin, it is evident that the trips in antiquity represented a genuine adventure, which some of the travellers must have found extremely appealing. Anyway, in those distant times, as it is a case today, there existed individuals possessing a huge sense of curiosity and need to delve into and explore the world that surrounded them, ready to invest effort and take a serious risk. Such motivation Anderson (cited in Hyde \& Lawson, 2003) designated properly as Ulysses fac- tor. Homer's hero Odysseus is indisputably the "spiritual father" of all the subsequent as well as today's adventure travellers.

\section{References}

Andriotis, K. (2009) Early Travellers to Greece and their Modern Counterparts. Paper presented at the Tourist Experiences: Meanings, Motivations, Behaviours, April 1-4 2009, University of Central Lancashire, Preston, UK.

Blumell, L. H. (2007) Beware of Bandits! Banditry and Land Travel in the Roman Empire. Journeys, 8, 1-20.

Casson, L. (1985) Travel in the Ancient World. Baltimore: The Johns Hopkins University Press.

Caton, R. (1914) Health Temples in Ancient Greece and the Work carried on in them. Proceedings of the Royal Society of Medicine, 7, 57-70.

Chambers, E. (2010) Native Tours: The Anthropology of Travel and Tourism. Long Grove: Waveland Press.

Cohen, E. (1972) Toward a sociology of international tourism. Social Research, 39, 16482.

Crowther, N. B. (2007) Sport in ancient times. Westport: Praeger Publishers

Delcourt, M. (1992) Delfijsko proročište (L'Oracle de Delphes). Sremski Karlovci, Novi Sad: Izdavačka knjižarnica Zorana Stojanovića.

Dillon, M. and Garland, L. (2010) Ancient Greece: Social and Historical Documents from Archaic Times to the Death of Alexander the Great. 3rd ed. Oxon: Routledge.

Enzensberger, H. M. (1983) Jedna teorija turizma. Turizam i kultura, 60/61, 11-29.

Feifer, M. (1985) Going Places: The Ways of the Tourist from Imperial Rome to the Present Day. London: Macmillan.

Flacelièrer, R. (1979) Grčka u doba Perikla (La vie quotidienne en Grèce au siècle de Périclès). Zagreb: Naprijed. 
Friedländer, L. [1907] (1965) Roman Life and Manners Under the Early Empire. 4 vols. Translated by L. A. Magnus. London: Routledge \& Kegan Paul.

García Romero, F. (2013) Sports tourism in Ancient Greece. Journal of Tourism History, 5(2), 146-160.

Garland, R. (2007) Ancient Greece: Everyday Life in the Birthplace of Western Civilization. New York: Sterling.

Geldard, R. G. (1989) The Travellers key to Ancient Greece (A Guide to the Sacred Places of Ancient Greece). London: Harrap Columbus.

Gyr, U. (2012) The History of Tourism: Structures on the Path to Modernity, European History Online, Mainz: Institute of European History. Available online: <http:// www.ieg-ego.eu/en/threads/europe-onthe-road/the-history-of-tourism $>$ [Accessed 15 October 2013].

Hudman, E. L. and Jackson, H. R. (2003) Geography of Travel and Tourism. 4th ed. New York: Thomson Delmar Learning.

Hyde, K. and Lawson, R. (2003) The nature of independent travel. Journal of Travel Research, 42(1), 13-23.

Jonkers, J. (2012) Athenian Presence in Delphi: An Investigation of the Epigraphical Evidence from Sixth and Fifth Century Delphi and Athens. RMA Thesis. Available online: <http://igitur-archive.library.uu.nl/ student-theses/2012-0816-200610/THESIS\%20-\%20Final\%20Version.pdf> [Accessed 23 October 2013].

Kitto, H. D. F. (1950) The Greeks. London: Penguin Books.

Korstanje, M. and Busby, G. (2010). Understanding the Bible as the Roots of Physical Displacement: The Origin of Tourism. e-Review of Tourism Research (eRTR), 8(3), 95-111.

Krippendorf, J. (1986) The new tourist - turning point for leisure and travel. Tourism Management, 7(2), 131-135.

Lascaratos, A.G. T. (1978) Kultura, baština i turizam. Turizam, 5, 26.
Lennon, J. and Foley, M. (2000) Dark tourism: The Attraction of Death and Disaster. London: Continuum.

Lomine, L. (2005) Tourism in Augustan Society (44BC - AD69). In: J.K. Waldton (ed.), Histories of Tourism: Representation, Identity and Conflict (pp. 71-87). Clevendon: Channel View Publications.

Lowenthal, D. (1999) The Past is a Foreign Country. Cambridge: Cambridge University Press.

Maksimović, B. (1951) Velika putovanja i geografska otkrića. Novi Sad: Matica srpska.

Mee, C. and Spawforth, A. (2001) Greece: An Oxford Archaeological Guide. Oxford: Oxford University Press.

Page, S. J. and Connell, J. (2009) Tourism: A Modern Synthesis. 3rd ed. Andover: Cengage Learning.

Perrottet, T. (2003) Pagan Holiday: On the Trail of Ancient Roman Tourists. New York: Random House.

Phoca, I. and Valavanis, P. (1999) Rediscovering ancient Greece: Architecture and City Planning. 3rd ed. Athens: Kedros Books.

Poon, A. (1993) Tourism, Technology and Competitive Strategies. Wallingford: CAB International.

Pretzler, M. (2007) Pausanias: Travel Writing in Ancient Greece. London: Duckworth.

Rabotić, B. (2013) Selektivni oblici turizma. 2nd ed. Beograd: Visoka turistička škola strukovnih studija.

Robinson, M. and Novelli, N. (2005) Niche tourism: an introduction. In: M. Novelli (ed.), Niche Tourism - contemporary issues, trends and cases (pp. 1-11). Oxford: Elsevier.

Scullion, S. (2007) "Pilgrimage" and Greek Religion: Sacred and Secular in the Pagan Polis. In: J. Elsner, and I. Rutherford (eds.), Pilgrimage in Graeco-Roman and Early Christian Antiquity: Seeing the Gods (pp. 111-120). Oxford: Oxford University Press.

Simón, M. F. (2010) From Thessalos of Tralles to Nicagoras of Athens: Religious pilgrim- 
age to Egypt in the Roman Empire. In: F.M. Simón, F. Pina Polo, and J.R. Rodríguez (eds.) Viajeros, Peregrinos y Aventureros en el Mundo Antiguo (pp. 227-240). Barcelona: Universitat de Barcelona.

Stark, D. J. (2009) Religious Tourism in Roman Greece. Theses and Dissertations (Comprehensive). Paper 951. Available online: $<$ http://scholars.wlu.ca/cgi/viewcontent. cgi? article $=1950 \&$ context $=$ etd $>$ [Accessed 16 October 2013].

Takács S. A. (1995) Alexandria in Rome. Harvard Studies in Classical Philology, 97, 263-276.

Towner, J. and Wall, G. (1992) History and Tourism. Annals of Tourism Research, 18, 71-84.

Vasoli, C. (1967) Putovanje, putevi i vozila. In: G. Giannelli, and U.E. Paoli, Antički Rim: panorama jedne civilizacije / Tutto su Roma antica, (p. 245-256). Beograd-Ljubljana: Vuk Karadžić, Prosveta, Mladinska knjiga.

Verhoeven, G. (2013) Foreshadowing Tourism: Looking for modern and obsolete features - or some missing link - in early modern travel behavior (1675-1750). Annals of Tourism Research, 42, 262-283.
Vukonić, B. (2012) An outline of the history of tourism theory: source material (for future research). In: C.H.C. Hsu, and W.C. Gartner (eds.), The Routledge Handbook of Tourism Research (pp. 3-26). Oxon: Routledge.

Vukonić, B. (2010) Turizam - budućnost mnogih iluzija (Tourism - The Future of Many Illusions). Zagreb: Visoka poslovna škola Utilus and Plejada.

Walton, J. K. (2009a) Histories of Tourism. In: T. Jamal, and M. Robinson (eds.) The SAGE Handbook of Tourism Studies (pp. 483-503). London: SAGE.

Walton, J. K. (2009b) Prospects in tourism history: Evolution, state of play and future developments. Tourism Management, 30, 783-793.

Webber, D. (2013) Space tourism: Its history, future and importance. Acta Astronautica, 92, 138-143.

Wong, K. K. F. and Cheung P.W.Y. (1999) Strategic theming in theme park marketing. Journal of Vacation Marketing, 5(4), 319332. 
